\title{
Cancer Epigenetics: Shifting to More Deep Action
}

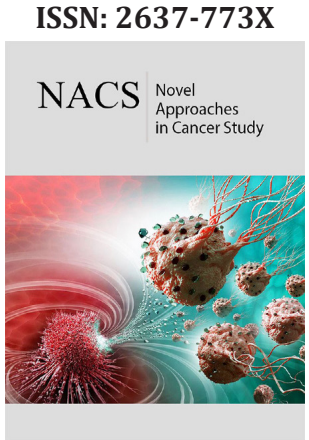

*Corresponding author: Hussein Sabit, Department of Genetics, Institute for Research and Medical Consultations, Dammam, 31441, Saudi Arabia

Submission: 望 May 01, 2019

Published: 㘹 May 28, 2019

Volume 2 - Issue 5

How to cite this article:Hussein $S$, Shimaa A-G, Emre C, Ferhad S E, Mokhtar E-Z. Cancer Epigenetics: Shifting to More Deep Action. Nov Appro in Can Study. 2(5). NACS.000548.2019.

DOI: 10.31031/NACS.2019.02.000548

Copyright@ Hussein Sabit, This article is distributed under the terms of the Creative Commons Attribution 4.0 International License, which permits unrestricted use and redistribution provided that the original author and source are credited.

\author{
Hussein Sabit ${ }^{1 *}$, Shimaa Abdel-Ghany ${ }^{2}$, Emre Cevik ${ }^{1}$, Ferhad Serag El-Deen ${ }^{3}$, \\ and Mokhtar El-Zawahri ${ }^{4,5}$
}

${ }^{1}$ Department of Genetics, Institute for Research and Medical Consultations, Imam Abdulrahman Bin Faisal University, Dammam, Saudi Arabia

${ }^{2}$ Department of Environmental Biotechnology, College of Biotechnology, Misr University for Science and Technology, Giza, Egypt

${ }^{3}$ Department of Biochemistry, Agriculture Research Center, Giza, Egypt

${ }^{4}$ Department of Medical and Pharmaceutical Biotechnology, College of Biotechnology, Misr University for Science and Technology, Giza, Egypt

${ }^{5}$ Center of Research and Development, Misr University for Science and Technology, Giza, Egypt

\begin{abstract}
Cancer is a major health problem facing the entire human population. It affects almost every race, gender, or age in the social hierarchy. Many mechanisms have been proposed for the development of cancer; either genetic or epigenetic. Over the years, a cumulative body of research indicated that epigenetic mutations (epimutations) represent a chief player in the course of cancer, where it affects cell proliferation, cancer initiation, progression, apoptosis, and metastasis. In this minireview we highlight the main mechanisms of epigenetic-mediated cancer development with emphasis on the environmental pollution role in this arena.
\end{abstract}

Keywords: Cancer; Epigenetics; Environment; miRNA; Methylation; Acetylation

Abbreviations: PAHs: Polycyclic Aromatic Hydrocarbons; AAs: Aromatic Amines; HAAs: Heterocyclic Aromatic Amines; AAS: 2-Amino-Apidic Semialdehyde; HAAs: Halo acetic acids; TSGs: Tumor Suppressor Genes; DNMT: DNA Methyltransferase; MECP2: Methyl CpG Binding Protein 2; MBD: Methyl-CpG-Binding Domain; HDAC: Histone Deacetylase; TGF: Transforming Growth Factor; LINE: Long Interspersed Nuclear Elements; Alu: Repeats characterized first in Arthrobacter luteus ; AAP: Accumulation Associated Protein; EZH2: Enhancer of Zeste Homolog 2; TMZ: Temozolomide; JMJD2C: Jumonji Domain 2; HATs: Histone Acetyl Transferase; Gcn5: General Control Nonderepressible-5; MYST: Histone Acetyltransferase KAT6A Its acronym comes from MOZ, YBF2/SAS3, SAS2 and TIP60 protein 3; CBP: CREB-Binding Protein; PTEN: Phosphatase and Tensin Homolog; APC: Adenomatous Polyposis Coli; IGF2: Insulin-like Growth Factor 2; IGF2R: Insulin-like Growth Factor 2 Receptor; PEG3: Paternally-Expressed Gene 3 Protein; GNAS: Guanine Nucleotide Binding Protein, Alpha Stimulating Activity Polypeptide; MEST: Mesoderm Specific Transcript; LOI: Loss of imprinting; CDKN2: Cyclin-dependent kinase inhibitor; KRAS: Kirsten RAt Sarcoma; HPRT: Hypoxanthine Phosphoribosyl transferase; DAPK: Death-Associated Protein Kinase; RAR- $\beta$ : Retinoic Acid Receptor Beta

\section{Introduction}

Cancer is a large group of more 100 different diseases that can arise anywhere in the human body [1-3]. It involves uncontrolled cellular proliferation, with the potential to invade or spread to other parts of the body [4]. Cancer is considered the second common leading cause of death worldwide. This condition was responsible for about 9.6 million deaths in 2018, where about 1 in 6 deaths is due to cancer [5]. Cancer arises from accumulation of genetic mutations and/or epigenetic mutations [6,7]. Several genes are involved in the carcinogenesis process, and they are reported elsewhere. The most common causes of cancer are epimutations, where environmental pollutions are the main players $[8,9]$. Epigenetics is a kind of non-sequence dependent inheritance, where a change in the DNA methylation, histone modification, among others, might cause cancer to develop [10-12]. Different mechanisms are involved in epigenetic-mediated carcinogenesis, each of them was extensively studied during the last four decades [6]. Interestingly, newly developed epigenetic-based cancer therapies provide unique and validated approach to treat different types of cancers $[13,14]$.

\section{Environmental Pollution and Cancer}

Outdoor air pollution is a global challenging life-threatening problem, where it is classified as a class I human carcinogen $[15,16]$. A large number of reports shows that air pollution is 
connected to increased risk of sever types of cancers including lung, head and neck, and nasopharyngeal cancers $[17,18]$. Other many diseases including respiratory diseases and heart disease are also correlated with prolonged exposure to polluted air [19,20]. Sources of air pollution include, but not limited to, industrial processes car fumes, and the household combustion of solid fuel [21]. All these sources contain specific chemicals that are known to be carcinogenic to humans.

\section{DNA adducts}

The chemical substances in polluted air can cause DNA damage (via adducts) [22]. These substances can trigger cancer through induction of severe immune responses such as oxidative stress and long-term inflammation in the upper aerodigestive tract [22, 23]. It has been reported by several research groups that DNA adducts have been found in individuals living in polluted regions, and this adducts might be associated with cancer development [24,25]. DNA isolated from individuals working in polluted environments showed 8-oxo-7,8-dihydro-2'-deoxyguanosine (8-oxo-dG) and bulky DNA adducts [26]. DNA adducts are covalent bonds occurs due to interaction of cancer-triggering chemical substances such as polycyclic aromatic hydrocarbons (PAHs) with DNA [27-29]. Some DNA adducts can be eliminated by specific repair proteins, while others are persistent, and the latter group is the main cause of pollution-related cancer initiation [30, 31]. Furthermore, persistent DNA adducts can cause base-pair substitutions, deletions and chromosomal rearrangements and other chromosomal abnormalities $[32,33]$.

DNA adducts, however, could be used as a reliable biomarker of exposure to carcinogens. Several studies were carried out to correlate DNA adducts with the occupation of individuals exposed. Categories include police officers [23,34,35], school children [36], bus and taxi drivers [24], and gasoline salesmen and roadside residents [22]. Meanwhile, chemical substances such as aromatic amines (AAs) and heterocyclic aromatic amines (HAAs) are activated by cytochrome P450 oxidation forming N-hydroxylated intermediates, which can react with DNA directly. The resultant compounds are transformed into unstable esters that induce genetic mutations [37]. Recently, several research groups developed specific DNA biomarker to detect the mutagenic effect of prolonged exposure to polluted air. The genes used in these studies involved CDKN2, p53, KRAS, HPRT, DAPK, and RAR- $\beta$ among others [38-41].

\section{Protein adducts}

Protein adducts could also be caused by air pollution, including benzopyrene-hemoglobin adducts and 4-aminophenyl-hemoglobin adducts in polluted areas [42]. The cancer-causing effects of these adducts have yet to be investigated experimentally [43]. Hemoglobin adducts formed by 4-aminobiphenyl was reported in a group of children living in polluted areas [44]. Furthermore, airborn substances were detected in proteins of exposed individuals in a suburban group. Higher levels of 2-amino-apidic semialdehyde (AAS) was observed in plasma proteins and in hemoglobin extracted from bus drivers, while malondialdehyde was observed in their plasma, and PAH was detected in their albumin [45]. Unfortunately, no repair mechanisms are there to handle protein adducts, and these adducts accumulate with chronic exposure to triggering factors. For that reason, hemoglobin $(\mathrm{Hb})$ and serum albumin carcinogen adducts could be used straightforwardly as a biomarker for AAs and HAAs exposure. Moreover, plasma levels of p53 and p2 $1^{\text {WAF1 }}$ proteins were found to be associated with exposure to PAHs and benzo[a]pyrene [46].

\section{Epigenetic Marks and Cancer}

Epigenetics is a wide-angled mechanism by which almost all biological processes are regulated. With regard to caner development, epigenetic-mediated gene regulation is involved in cancer initiation, progression, metastasis, and angiogenesis, along with cancer stem cell induction as a primary step towards initiating the cascade $[47,48]$. Players of epigenetic landscape could be classified into different classes; on DNA level, histone level, miRNA level, and imprinting.

\section{Cytosine Methylation}

Cytosine methylation is the most common epigenetic mark in cancer [49-51]. Normally, cytosine (occurs in $\mathrm{CpG}$ dinucleotide) is methylated in a high percentage of human genome sequences to maintain chromosome stability, while those CpGs located in promote regions, especially of tumor suppressor genes, are normally hypomethylated $[52,53]$. These hypo- or un-methylated promoter regions allow for transcription of TSGs that have crucial roles in controlling cell proliferation. The methyl group in the $5 \mathrm{mC}$ lies in the major groove of the double helix DNA and interfere with binding of transcription factor, and hence avert gene expression [54]. Upon adding the methyl group to the fifth carbon atom in cytosine residue by the action of DNMT, methylated DNA-binding proteins such as MECP2 and the MBD protein family were recruited to bind to methylated cytosines and suppress transcription process by hindering the attachment of transcription factors [55].

Histone deacetylase (HDAC) was also recruited to remove the acetyl groups from the histone tails rendering it to closed structure in this case, it is known as heterochromatin [56,57]. If these actions took place in the promoter region, the no RNA polymerase would be able to attach its specific site to start transcription, and hence the corresponding gene in this case is said to be silenced. Methylation always occurs in $\mathrm{CpG}$ dinucleotides either in regions rich of these $\mathrm{CpGs}$ (CpG islands) or within the body of the gene [58]. Hypermethylation of tumor suppressor genes is positively correlated with the initiation of cancer in different organs [59].

Our studies indicated that global DNA methylation was increases in traffic workers with exposure to car fumes in Cairo, Egypt [60]. This study indicated that tumor (transforming) growth factor (TGF) was found to be hypermethylated in traffic workers exposed to car fumes for a long time (more than 6 hours/day for at least 5 years). Furthermore, $P 53$ was also found by our group to be dysregulated in people exposed to car fumes for a long time in a cohort population in Egypt (unpublished data). Hypermethylation and/or dysregulation of these genes might indicate a future cancer incidence in individual 
with these recorded abnormalities. On the other hand, many drugs have been designed to modulate the methylome of malignant cells as a way of treatment. In our laboratory, we investigated different kind of DNMT inhibitors such as procaine and cyclophosphamide in different cancer cells including breast, colon, liver, cervical, lung, and laryngeal cancer [61-64].

\section{Repetitive sequences}

Repetitive elements constitute a large percentage of the human genome. It is normally hypermethylated, while in cancer, it becomes hypomethylated [65]. Various types of repeats in human genome including LINE-1, Alu, centromeric tandem repeats, and juxta centromeric tandem repeats are considered the most frequently studied repetitive sequences in cancer, where it was found to be hypomethylated. In addition, hypomethylation of these repeats allows it to jump to other genomic loci [66]. Global hypomethylation of LINE-1 and Alu was associated with long term or short-term exposure to AAP. Specifically, genome wide hypomethylation of Alu and LINE-1 repeats might lead to repositioning of these sequences, leading to insertional mutations and genomic instability $[67,68]$. On the other hand, centromeric tandem repeats, and juxta centromeric tandem repeats play a crucial role in maintaining DNA wrapped within heterochromatin structure, where no transcription is allowed at the point of sister chromatid association. This heterochromatinization leads to chromosome stability. Therefore, hypomethylation of these repeats allows for heterochromatin to be transformed to more open form i.e., euchromatin, leading to chromosome rearrangements, and hence, genomic instability [69].

\section{Histone methylation}

The histone methylation has been widely proven to regulate transcription $[70,71]$. The methylation of histone tail residue is associated with both activation and suppression of transcription [72]. Histone methylation occurs in the residues of arginine and lysine on the histone tails $\mathrm{H} 3$ and $\mathrm{H} 4$ proteins [47]. Lysine methylation is stimulated by histone-lysine- $\mathrm{N}$-methyltransferases also known as K-methyltransferases and involves the transport of methyl groups from the S-adenosyl methionine. EZH2 (Zeste 2) is one of the main proteins involved in the control and differentiation of stem cells, K-methyltransferase, which stimulates the trimethylation of methyl H3K27 [71,73].

EZH2 is a member of the polycomb repressive complex 2, a protein compound that contains both the K-methyltransferase protein and the reader proteins that recognizes the H3K27me3 $[74,75]$. H3K27me3 is usually involved in silencing genes associated with the evolution and differentiation of stem cells, including the Hox genes [76,77]. However, in many cancers, EZH2 is expressed excessively at both transcriptional and protein levels. Overexpression of EZH2 has been designated as vital in prostate cancer, where an increase in EZH2 protein staining in the cell nucleus was detected with a progression from benign to metastatic disease $[78,79]$. Other studies have identified excessive expression of EZH2 as a key feature of breast cancer, lymphoma and glaucoma, among other cancers [80-82]. In cancer cells, H3K27me3 was also shown to suppress gene expression independently of the DNA methylation, whereas in normal cells, EZH2 was shown to control DNA methylation through interaction with DNMTs [83]. In addition, dysregulation has recently been described in other members of the polycomb repressive complex, including proteins that interact with polycomb repressive complex 2 after the modulation of $\mathrm{H} 3 \mathrm{~K} 27 \mathrm{me} 3$ mark by EZH2 $[84,85]$. In contrast to H3K27me3-mediated silencing of histone, histone methylation can also be a marker associated with activation of transcription [86]. Currently, we are using temozolomide (TMZ) as a histone methylation agent in colorectal cancer cells to identify its interaction with other histone tags (unpublished data). JMJD2C is K-demethylase which stimulates the removal of methyl markers from $\mathrm{H} 3 \mathrm{~K} 9$, a histone marker that is commonly associated with suppression of gene expression [87]. JMJD2C has been detected in many types of cancers, including esophageal and breast cancers [88]. Lysine demethylase 1, a type of K-demethylase, which targets H3K9 and H3K4, has recently found to be overexpressed in ER- breast cancer caused by estrogen receptors, mesothelioma, and bladder cancer [88].

Although more research is needed to understand the functional consequences of dysregulation of histone, K-demethylases and K-methyltransferases are important in the cancer-causing process and represent new targets for treatment. Our current work involves modulating $\mathrm{H} 3 \mathrm{~K} 27 \mathrm{me} 3$ to control breast cancer. We are aiming to demethylate this histone mark using demethylating agent such as 5-Aza cytidine.

\section{Histone acetylation}

Unlike histone methylation, acetylation of histone is sturdily connected to transcription activation $[89,90]$. Acetylation of histone occurs on the lysine residues and is believed to enhance transcription by neutralizing the positively charged histones, thereby reducing its interaction with the negatively charged DNA [91]. The maintenance of histone marks is controlled by histone acetyl transferase (HATs), also known as K-acetyltransferases, and histone deacetylases [92]. HATs stimulate the addition of acetyl groups to lysine using acetyl coenzyme A as a cofactor, thereby transforming the chromatin structure to be euchromatin. On the other hand, HDACs remove acetyl groups and induce a closed or suppressive chromatin structure (heterochromatin) [93].

Three diverse families of HATs are known; the Gcn5 family, the MYST family, and the p300/CBP family [94,95]. It turns out that the HATs of each of these families play a role in causing cancer, either from improper activation or suppression of the target gene activity [96]. The Wnt signaling pathway, previously shown to be dysregulated in some types of cancers, is now indicated to be enhanced by HAT Gcn 5 in breast cancer [97]. HDACs, in human, are a group 18 enzymes that catalyze the removal of histone acetyl marks and are involved in repressing the transcription process in several cancer-related genes such as p53, PTEN, APC, and p21 [56,98]. Several cancer studies have indicated that histone deacetylation is an early step in carcinogenesis process [99-101]. In rat model with skin cancer, early loss of mono-acetylation of histone H4K16 was 
detected, indicating the role of deacetylation in promoting cancer [102].

Furthermore, histone deacetylation was also observed in different malignant cell lines including breast cancer, colon cancer, and lymphoma cells signifying that histone deacetylation is a common event in cancer [103]. The deregulation of HDAC in cancer cells offers a new target for chemotherapy i.e., HDAC inhibitors (HDACi). HDAC inhibitors are widely used as a therapeutic option in several diseases, including cancer. We extensively used Vorinostat (one of the FDA approved HDACi) in different cell lines to identify its role in controlling the progression of the disease [104].

\section{miRNAs and cancer}

MicroRNAs (miRNAs) are a type of small (20-24 nucleotides) non-coding RNA molecules that play a central role in posttranscriptional regulation of gene expression $[105,106]$. Since its discovery in 1993, several studies have proven its role as oncogenes (oncomiRs) or tumor suppressors (anti-oncomiRs), under certain conditions in human cancers, including colorectal, liver, lung, breast, and brain cancer [107]. In these cancers, it has been shown that uncontrolled miRNAs affect the distinctive features of cancer, including the maintenance of proliferative signals, the evasion of growth inhibitors, resistance to cell death, invasion activation and metastasis (metastamiRs), and angiogenesis (angiomiRs) [108].

Convincing evidence has shown that miRNA expression is unregulated in human cancer through various mechanisms, including amplification or deletion of miRNA genes, atypical miRNA control, abnormal epigenetic changes and defects in the miRNA biosynthesis pathway [105]. Furthermore, because of their complicated role in cancer, miRNAs represent attractive candidates for cancer treatment italic synthesizing either miRNA antagonists or miRNA mimics to suppress or augment specific miRNA expression, respectively.

\section{Genomic imprinting}

Genomic imprinting is type of inheritance that does not follow the usual Mendelian type of inheritance [109]. It is an epigenetic phenomenon that causes some genes to be differentially expressed based on their parent of origin [110]. This process involves DNA methylation and histone modification as epigenetic marks without affecting the sequence of DNA. Nearly 100 genes have been characterized so far, and a number of these genes have been implicated in the development of tumors. Examples of human imprinted genes are IGF2, IGF2R, PEG3, GNAS, and MEST [111,112]. The physiological role of many of the imprinted genes in controlling cell proliferation suggesting their potential involvement in tumor formation process [113]. Because most of the imprinted genes play central roles in cellular growth, development, and metabolism, the abnormal expression of these genes either due to genetic or epigenetic mutations often causes human ailments, including cancers [114]. For example, loss of imprinting (LOI) in IGF2 due to abnormal methylation of differentially methylated regions has been observed in many types of tumors [115].

\section{Conclusion}

Cancer is a disease that arise from the consecutive buildup of genetic and epigenetic changes in cells. Notwithstanding powerful studies, several questions remain unanswered about the exact role of epigenetics in cancer initiation and progression. The proposed mechanisms have accounted for a small percentage of the entire story, and the rest is demanding further investigation. Being the future field of studying cancer, epigenetic-based drugs (epidrugs) were introduced. These drugs might replace the well-known medications that target only symptoms, but not the core cause of diseases.

\section{References}

1. Bingham J, Dyer M, Steele SR (2019) Chapter 169- Abdominoperineal resection for rectal cancer, in shackelford's surgery of the alimentary tract. In: Yeo CJ (Ed.), Content Repository Only ( $8^{\text {th }}$ edn), Philadelphia, USA, 2: 2035-2048.

2. Kalady MF, Boland CR, Church JM (2019) Chapter 165 - Inherited colorectal cancer and the genetics of colorectal cancer, in shackelford's surgery of the alimentary tract. In: Yeo CJ (Ed.), Content Repository Only ( $8^{\text {th }}$ edn), Philadelphia, USA, 2: 1959-1980.

3. Brown M, Cato L, Jeselsohn R (2019) Chapter 29-Hormone responsive cancers, in yen and jaffe's reproductive endocrinology. In: Strauss JF, Barbieri RL (Eds.), Content Repository Only ( $8^{\text {th }}$ edn), Philadelphia, USA, pp.717-741.e8.

4. Sharma A, et al. (2019) Chapter 77 - Immunotherapy of cancer, in clinical immunology. In: Rich RR, et al. (Eds.), Content Repository Only ( $5^{\text {th }}$ edn), London, UK, pp. 1033-1048.e1.

5. Siegel RL, Miller KD, Jemal A (2019) Cancer statistics, 2019. CA Cancer J Clin 69(1): 7-34.

6. Garcia GA, Rodriguez J, Ballestar E (2018) Epigenetic interplay between immune, stromal and cancer cells in the tumor microenvironment. Clin Immunol 196: 64-71.

7. Klajic J, Kristensen V (2018) Epigenetics of breast cancer: pp.141-168.

8. Choudhuri S, Chanderbhan R, Mattia A (2018) Chapter 20- Carcinogenesis: mechanisms and models*, in veterinary toxicology. In: Gupta RC (Ed.), Academic Press ( ${ }^{\text {rd }}$ edn), Cambridge, Massachusetts, United States, pp. 339-354.

9. Singh A, Gill G, Jakhu H (2018) Epigenetics and its implications for oral health. Journal of Oral Biosciences 60(2): 41-48.

10. Sandoval BJ, González GR, Bologna MR, Isiordia EM, Leija MG, et al. (2018) Epigenetic mechanisms in odontogenic tumors: A literature review. Arch Oral Biol 87: 211-217.

11. Stolfi DH, Alba E (2018) Epigenetic algorithms: A new way of building GAs based on epigenetics. Information Sciences 424: 250-272.

12. Peedicayil J, Grayson DR (2018) An epigenetic basis for an omnigenic model of psychiatric disorders. J Theor Biol 443: 52-55.

13. Roque FR (2018) Chapter 13 - Epigenetic regulation of endothelial function: with focus on microRNAs, in endothelium and cardiovascular diseases. In: Da Luz PL, et al. (Eds.), Academic Press, Cambridge, Massachusetts, United States, pp.171-187.

14. Supic G, Zeljic K, Magic Z (2018) Epigenetic nutraceuticals in cancer treatment, in therapeutic foods. In: Holban AM and Grumezescu AM (Eds.), Academic Press, Cambridge, Massachusetts, United States, pp. 449-493.

15. Sigaux J, Biton J, André E, Semerano L, Boissier MC (2018) Air pollution as a determinant of rheumatoid arthritis. Joint Bone Spine 86(1): 37-42. 
16. Finch CE (2018) Air pollution in our future longevity, in the role of global air pollution in aging and disease. In: Finch CE (Ed.), Academic Press, Cambridge, Massachusetts, United States, pp.161-194.

17. Krauskopf J, Caiment F, van Veldhoven K, Chadeau-Hyam M, Sinharay R, et al. (2018) The human circulating miRNome reflects multiple organ disease risks in association with short-term exposure to traffic-related air pollution. Environment International 113: 26-34.

18. Fougère B, Landkocz Y, Lepers C, Martin PJ, Armand L, et al. (2018) Influence of aging in the modulation of epigenetic biomarkers of carcinogenesis after exposure to air pollution. Experimental Gerontology 110: 125-132.

19. Olvera Alvarez HA, Kubzansky LD, Campen MJ, Slavich GM (2018) Early life stress, air pollution, inflammation, and disease: An integrative review and immunologic model of social-environmental adversity and lifespan health. Neuroscience \& Biobehavioral Reviews 96: 226-242.

20. Barrow TM (2018) Chapter 8 - Epigenetic epidemiology for cancer risk, in epigenetic mechanisms in cancer. In: Saldanha S (Ed.), Academic Press: Boston, Massachusetts, United States, pp. 195-222.

21. Finch CE (2018) Chapter 3 - Air pollution in diseases of aging, in the role of global air pollution in aging and disease. In: Finch CE (Ed.), Academic Press, Cambridge, Massachusetts, United States, pp. 83-130.

22. Ayi Fanou L, Avogbe PH, Fayomi B, Keith G, Hountondji C, et al. (2011) DNA-adducts in subjects exposed to urban air pollution by benzene and polycyclic aromatic hydrocarbons (PAHs) in Cotonou, Benin. Environ Toxicol 26(1): 93-102.

23. Merlo F, Bolognesi C, Peluso M, Valerio F, Abbondandolo A, et al. (1997) Airborne levels of polycyclic aromatic hydrocarbons: 32P-postlabeling DNA adducts and micronuclei in white blood cells from traffic police workers and urban residents. J Environ Pathol Toxicol Oncol 16(2-3): 157-62.

24. Hemminki, K, Zhang LF, Krüger J, Autrup H, Törnqvist M, et al. (1994) Exposure of bus and taxi drivers to urban air pollutants as measured by DNA and protein adducts. Toxicol Lett 72(1-3): p. 171-174.

25. Geretto M, Ponassi M, Casale M, Pulliero A, Cafeo G, et al. (2018) A novel calix [4] pyrrole derivative as a potential anticancer agent that forms genotoxic adducts with DNA. Scientific Reports 8(1): 11075.

26. Taggart DJ, Fredrickson SW, Gadkari VV, Suo Z (2014) Mutagenic potential of 8-oxo-7,8-dihydro-2'-deoxyguanosine bypass catalyzed by human Y-family DNA polymerases. Chemical Research in Toxicology 27(5): 931 940.

27. Ewa B, Danuta MŠ (2017) Polycyclic aromatic hydrocarbons and PAH-related DNA adducts. Journal of Applied Genetics 58(3): 321-330.

28. Siddens LK, Bunde KL, Harper TA, McQuistan TJ, Löhr CV, et al. (2015) Cytochrome P450 1b1 in polycyclic aromatic hydrocarbon (PAH)-induced skin carcinogenesis: Tumorigenicity of individual PAHs and coaltar extract, DNA adduction and expression of select genes in the Cyp1b1 knockout mouse. Toxicology and Applied Pharmacology 287(2): 149160.

29. Wang YY, Wang W, Yang J, Li GL, Zhuang LK, et al. (2015) Relationship of GSTT1 and GSTM1 gene polymorphisms and PAH-DNA adducts with pathogenesis of multiple myeloma. Zhongguo Shi Yan Xue Ye Xue Za Zhi 23(3): 728-732.

30. Yimit A, Adebali O2, Sancar A, Jiang Y (2019) Differential damage and repair of DNA-adducts induced by anti-cancer drug cisplatin across mouse organs. Nature Communications10(1): 309.

31. Poirier MC, Lair S, Michaud R, Hernández EE, Divi KV, et al. (2019) Intestinal polycyclic aromatic hydrocarbon-DNA adducts in a population of beluga whales with high levels of gastrointestinal cancers. Environmental and Molecular Mutagenesis 60(1): 29-41.

32. Ross JA, Nelson GB, Mutlu E, Warren SH, Gilmour MI, et al. (2015) DNA adducts induced by in vitro activation of extracts of diesel and biodiesel exhaust particles. Inhalation Toxicology 27(11): 576-584.

33. Rajalakshmi TR, Aravindha Babu N, Shanmugam KT, Masthan KM, et al. (2015) DNA adducts-chemical addons. Journal of Pharmacy and Bioallied Sciences 7(Supp 1): S197-S199.

34. Ruchirawa M, Mahidol C, Tangjarukij C, Pui-ock S, Jensen O, et al. (2002) Exposure to genotoxins present in ambient air in Bangkok, Thailand--particle associated polycyclic aromatic hydrocarbons and biomarkers. Sci Total Environ 287(1-2): 121-32.

35. Topinka J, Sevastyanova O, Binkova B, Chvatalova I, Milcova A, et al. (2007) Biomarkers of air pollution exposure-a study of policemen in Prague. Mutat Res 624(1-2): 9-17.

36. Tuntawiroon J, Mahidol C, Navasumrit P, Autrup H, Ruchirawat M (2007) Increased health risk in Bangkok children exposed to polycyclic aromatic hydrocarbons from traffic-related sources. Carcinogenesis 28(4): 816822.

37. Pathak KV, Chiu TL, Amin EA, Turesky RJ (2016) Methemoglobin formation and characterization of hemoglobin adducts of carcinogenic aromatic amines and heterocyclic aromatic amines. Chemical Research in Toxicology 29(3): 255-269.

38. Gealy R, Zhang L, Siegfried JM, Luketich JD, Keohavong P (1999) Comparison of mutations in the p53 and K-ras genes in lung carcinomas from smoking and nonsmoking women. Cancer Epidemiol Biomarkers Prev 8(4 Pt 1): 297-302.

39. Keohavong P, Lan Q, Gao WM, Zheng KC, Mady HH, et al. (2005) Detection of p53 and K-ras mutations in sputum of individuals exposed to smoky coal emissions in Xuan Wei County, China. Carcinogenesis 26(2): 303338.

40. Granville CA, Hanley NM, Mumford JL, DeMarini DM (2003) Mutation spectra of smoky coal combustion emissions in Salmonella reflect the TP53 and KRAS mutations in lung tumors from smoky coal-exposed individuals. Mutat Res 525(1-2): 77-83.

41. Hosgood HD, Pao W, Rothman N, Hu W, Pan YH, et al. (2013) Driver mutations among never smoking female lung cancer tissues in China identify unique EGFR and KRAS mutation pattern associated with household coal burning. Respir Med 107(11): 1755-1762.

42. Heymann HM, Gardner AM, Gross ER (2018) Aldehyde-iduced DNA and protein adducts as biomarker tools for alcohol use disorder. Trends Mol Med 24(2): 144-155.

43. Phillips DH, Venitt S (2012) DNA and protein adducts in human tissues resulting from exposure to tobacco smoke. International Journal of Cancer 131(12): 2733-2753.

44. Bukowska B (2015) Hemoglobin adducts as biomarkers of human exposure to selected xenobiotics. Postepy Hig Med Dosw (Online) 69: 668680.

45. Autrup H, Daneshvar B, Dragsted LO, Gamborg M, Hansen M, et al. (1999) Biomarkers for exposure to ambient air pollution-comparison of carcinogen-DNA adduct levels with other exposure markers and markers for oxidative stress. Environmental Health Perspectives 107(3): 233-238.

46. Wong ICK, YK Ng, Lui VWY (2014) Cancers of the lung, head and neck on the rise: perspectives on the genotoxicity of air pollution. Chinese journal of cancer 33(10): 476-480.

47. Watson RE (2014) Epigenetics, in encyclopedia of toxicology. In: Wexler P (Ed.), Academic Press ( $3^{\text {rd }}$ edn), Oxford, United Kingdom, pp. 438-443.

48. Wainwright EN, Scaffidi P (2017) Epigenetics and cancer stem cells: unleashing, hijacking, and restricting cellular plasticity. Trends in Cancer 3(5): 372-386.

49. Bakulski KM, Dou J, Lin N, London SJ, Colacino JA (2019) DNA methylation signature of smoking in lung cancer is enriched for exposure signatures in newborn and adult blood. Scientific Reports 9(1): 4576. 
50. Shen XF, Yuan HB, Wang GQ, Xue H, Liu YF, et al. (2019) Role of DNA hypomethylation in lateral habenular nucleus in the development of depressive-like behavior in rats. Journal of Affective Disorders 252: 373381.

51. Georgiadis P, Gavriil M, Rantakokko P, Ladoukakis E, Botsivali M, et al. (2019) DNA methylation profiling implicates exposure to PCBs in the pathogenesis of B-cell chronic lymphocytic leukemia. Environ Int 126: 24-36.

52. Kessler M, Hoffmann K, Fritsche K, Brinkmann V, Mollenkopf HJ, et al. (2019) Chronic Chlamydia infection in human organoids increases stemness and promotes age dependent CpG methylation. Nat Commun 10(1): 1194.

53. Brinkman AB, Zainal SN, Simmer F, González FGR, Smid M, et al. (2019) Partially methylated domains are hypervariable in breast cancer and fuel widespread CpG island hypermethylation. Nat Commun 10(1): 1749.

54. Skvortsova K, Farquhar EM, Luu PL, Song JZ, Qu W, et al. (2019) DNA hypermethylation encroachment at $\mathrm{CpG}$ island borders in cancer is predisposed by $\mathrm{H}_{3} \mathrm{~K}_{4}$ Monomethylation Patterns. Cancer Cell 35(2): 297-314.

55. Miao Cg, Qin D, Du CL, Ye H, Shi WJ, et al. (2015) DNMT1 activates the canonical WNT signaling in rheumatoid arthritis model rats via a crucial functional crosstalk between miR-152 and the DNMT1, MeCP 2 . Int Immunopharmacol 28(1): 344-353.

56. Laws MT, Bonomi RE, Kamal S, Gelovani DJ, Llaniguez J, et al. (2019) Molecular imaging HDACs class IIa expression-activity and pharmacologic inhibition in intracerebral glioma models in rats using PET/CT/(MRI) with $\left[{ }^{18} \mathrm{~F}\right]$ TFAHA. Sci Rep 9(1): 3595.

57. Bayat S, Derakhshan SM, Derakhshan NM, Khaniani MS, Alivand MR (2019) Downregulation of $\mathrm{HDAC}_{2}$ and $\mathrm{HDAC}_{3}$ via oleuropein as a potent prevention and therapeutic agent in MCF-7 breast cancer cells. Journal of Cellular Biochemistry 120(6): 9172-9180.

58. Cardelli M (2018) The epigenetic alterations of endogenous retroelements in aging. Mech Ageing Dev 174: 30-46.

59. Selmin OI, Donovan MG, Skovan B, Murieta GDP, Romagnolo DF (2019) Arsenic-induced BRCA1 CpG promoter methylation is associated with the downregulation of $\mathrm{ER} \alpha$ and resistance to tamoxifen in $\mathrm{MCF}_{7}$ breast cancer cells and mouse mammary tumor xenografts. Int J Oncol 54(3): 869-878.

60. Shaat R, Ghany SEA, Nasr GM, Sabit H, Zawahry M (2019) Modulation of epigenetic profiles in traffic workers exposed to car fumes in Egypt. Molecular Biology: Open Access 8(1): 1-7.

61. Sobhy S, Ghareeb AWE, Aziz SA, Sabit H (2016) Epigenetic regulation of P21, RASSF1, PTEN and P53 in human breast cancer cells using different chemotherapeutic drugs. Academic Journal of Cancer Research 9(2): 26-34.

62. Sabit H, Samy MB, Said AMO, Zawahri MME (2016) Procaine induces epigenetic changes in HCT116 colon cancer cells. Genetics Research International, p. 1-7.

63. Sabit H, Garhy ATE, Zawahry MME (2016) The role of sodium phenylbutyrate in modifying the methylome of breast cancer cells. International Journal of Scientific \& Engineering Research 7(10): 677-683.

64. Sabit H, Sattar A, Arwa S, Ghany A, Shimaa E, et al. (2015) Cyclophosphamide with adjuvant chemotherapeutic drugs induces epigenetic changes in hepatocellular carcinoma cells. Cancer Biology 5(4): 26-34.

65. Lander ES, Linton LM, Birren B, Nusbaum C, Zody MC, et al. (2001) Initial sequencing and analysis of the human genome. Nature 409(6822): 860-921.

66. Ehrlich M (2002) DNA methylation in cancer: too much, but also too little. Oncogene 21(35): 5400-5413.

67. Brennan K, Flanagan JM (2012) Is there a link between genome-wide hy pomethylation in blood and cancer risk? Cancer Prev Res (Phila) 5(12): 1345-1357.
68. Veeck J, Esteller M (2010) Breast cancer epigenetics: from DNA methylation to microRNAs. J Mammary Gland Biol Neoplasia 15(1): 5-17.

69. Eden A, Gaudet F, Waghmare A, Jaenisch R (2003) Chromosomal instability and tumors promoted by DNA hypomethylation. Science 300(5618): 455 .

70. Huang $\mathrm{H}$, Weng $\mathrm{H}$, Zhou $\mathrm{K}$, Wu T, Zhao BS, et al. (2019) Histone $\mathrm{H}_{3}$ trimethylation at lysine 36 guides $\mathrm{m}^{6} \mathrm{~A}$ RNA modification co-transcriptionally. Nature 567(7748): 414-419.

71. Wickramasekara RN, Stessman HAF (2019) Histone 4 lysine 20 methylation: A case for neurodevelopmental disease. Biology (Basel) 8(1).

72. Gong F, Miller KM (2017) Histone methylation and the DNA damage response. Mutation Research/Reviews in Mutation Research.

73. Rowe EM, Xing V, Biggar KK (2019) Lysine methylation: Implications in neurodegenerative disease. Brain Res 1707: 164-171.

74. Zheng S, Hongmiao Hu, Huimin Ren, Yang Z, Qi Qiu, et al. (2019) The Arabidopsis $\mathrm{H}_{3} \mathrm{~K}_{27} \mathrm{me}_{3}$ demethylase JUMONJI 13 is a temperature and photoperiod dependent flowering repressor. Nature Communications 10(1): 1-11.

75. Kaneshiro KR, Rechtsteiner A, Strome S (2019) Sperm-inherited H3K27me3 impacts offspring transcription and development in C. elegans. Nature Communications 10(1): 1-9.

76. Lin Y, Juan Y, Jinxing W, Wang S, Zhang T (2019) Abnormal level of CUL4B-mediated histone $\mathrm{H}_{2} \mathrm{~A}$ ubiquitination causes disruptive HOX gene expression. Epigenetics and Chromatin 12(1): 1-17.

77. Chen X, Mengying W, Xiangwei L, Shuang S, Lei W, et al. (2019) Construction and validation of the CRISPR/dCas9-EZH2 system for targeted $\mathrm{H}_{3} \mathrm{~K}_{27} \mathrm{Me}_{3}$ modification. Biochemical and Biophysical Research Communications 511(2): 246-252

78. Weaver TM, Jiachen L, Connelly KE, Coble C, Varzavand K, et al. (2019) The $\mathrm{EZH}_{2}$ SANT1 domain is a histone reader providing sensitivity to the modification state of the H4 tail. Scientific Reports 9(1): 1-11.

79. Cai Q, Niu H, Zhang B, Shi X, Liao M, et al. (2019) Effect of EZH knockdown on preimplantation development of porcine parthenogenetic embryos. Theriogenology 132: 95-105.

80. Deng H, Guan X, Gong L, Zenget J, Zhang H, et al. (2019) CBX $_{6}$ is negatively regulated by $\mathrm{EZH}_{2}$ and plays a potential tumor suppressor role in breast cancer. Scientific Reports 9(1): 1-13

81. Huang S, Wang Z, Zhou J, Huang J, Zhou L, et al. (2019) $\mathrm{EZH}_{2}$ inhibitor GSK126 suppresses antitumor immunity by driving production of myeloid-derived suppressor cells. Cancer Research 79(8): 2009-2020.

82. Genta S, Pirosa MC, Stathis A (2019) BET and EZH inhibitors: Novel approaches for targeting cancer. Curr Oncol Rep 21(2): 13.

83. Xiang S, Zou P, Tang Q, Zheng F, Wu J, et al. (2018) HOTAIR-mediated reciprocal regulation of $\mathrm{EZH}_{2}$ and DNMT1 contribute to polyphyllin I-inhibited growth of castration-resistant prostate cancer cells in vitro and in vivo. Biochim Biophys Acta Gen Subj 1862(3): 589-599.

84. Grindheim JM, Nicetto D, Donahue G, Zaret KS (2019) Polycomb repressive complex 2 proteins $\mathrm{EZH}_{1}$ and $\mathrm{EZH}_{2}$ regulate timing of postnatal hepatocyte maturation and fibrosis by repressing genes with euchromatic promoters in mice. Gastroenterology 156(6): 1834-1848.

85. Chou J, Ferris AC, Chen T, Seok R, Yoon D, et al. (2019) Roles of Polycomb group proteins Enhancer of zeste $(\mathrm{E}(\mathrm{z}))$ and Polycomb $(\mathrm{Pc})$ during metamorphosis and larval leg regeneration in the flour beetle Tribolium castaneum. Dev Biol 450(1): 34-46.

86. Wang T, Pickard AJ, Gallo JM (2016) Histone methylation by temozolomide; A classic DNA methylating anticancer drug. Anticancer Research 36(7): 3289-3299.

87. Voon HPJ, Udugama M, Lin W, Hii L, Law RHP, et al. (2018) Inhibition of a K9/K36 demethylase by an H3.3-point mutation found in paediatric glioblastoma. Nature Communications 9(1): 3142. 
88. Pedersen MT, Agger K, Laugesen A, Johansen JV, Cloos PA, et al. (2014) The demethylase JMJD2C Localizes to H3K4me3-positive transcription start sites and is dispensable for embryonic development. Molecular and Cellular Biology 34(6): 1031-1045.

89. Borodinova AA, et al. (2019) Histone acetylation determines transcription of atypical protein kinases in rat neurons. Scientific Reports 9(1).

90. Ming J, Wu S, You T, Wang X, Yu C, et al. (2019) Histone deacetylation in the promoter of p16 is involved in fluoride-induced human osteoblast activation via the inhibition of Sp1 binding. Biological Trace Element Research 188(2): 373-383.

91. Chrun ES, Modolo F, Daniel FI (2017) Histone modifications: A review about the presence of this epigenetic phenomenon in carcinogenesis. Pathology Research and Practice 213(11): 1329-1339.

92. Ganai SA, Banday S, Farooq Z, Altaf M (2016) Modulating epigenetic HAT activity for reinstating acetylation homeostasis: A promising therapeutic strategy for neurological disorders. Pharmacology \& Therapeutics 166: 106-122.

93. Gong F, Miller KM (2013) Mammalian DNA repair: HATs and HDACs make their mark through histone acetylation. Mutation Research/Fundamental and Molecular Mechanisms of Mutagenesis 750(1): 23-30.

94. Namwanje M, Liu L, Chan M, Aaron N, Kraakman MJ, et al. (2019) The depot-specific and essential roles of $\mathrm{CBP} / \mathrm{p} 300$ in regulating adipose plasticity. Journal of Endocrinology 240(2): 257-269.

95. Gorsuch S, Bavetsias V, Rowlands MG, Aherne GW, Workman P, et al (2009) Synthesis of isothiazol-3-one derivatives as inhibitors of histone acetyltransferases (HATs). Bioorganic \& Medicinal Chemistry 17(2): 467-474.

96. Bruserud O, Stapnes C, Ersvaer E, Gjertsen BT, Ryningen A (2007) Histone deacetylase inhibitors in cancer treatment: a review of the clinical toxicity and the modulation of gene expression in cancer cell. Curr Pharm Biotechnol 8(6): 388-400.

97. Hirota M, Watanabe K, Hamada S, Sun Y, Strizzi L, Mancino M, et al. (2008) Smad2 functions as a co-activator of canonical Wnt/beta-catenin signaling pathway independent of Smad4 through histone acetyltransferase activity of p300. Cellular signaling 20(9): 1632-1641.

98. Zhang Q Wang S, Chen J, Yu Z (2019) Histone deacetylases (HDACs) guided novel therapies for T-cell lymphomas. International Journal of Medical Sciences 16(3): 424-442.

99. Yu Z, Zeng J, Liu H, Wang T, Yu Z, et al. (2019) Role of HDAC1 in the progression of gastric cancer and the correlation with lncRNAs. Oncology Letters 17(3): 3296-3304.

100. Manzotti G, Ciarrocchi A, Sancisi V (2019) Inhibition of BET proteins and histone deacetylase (HDACs): Crossing roads in cancer therapy. Cancers 11(3).

101. Kiesslich T, Neureiter D (2019) HDAC inhibitors in liver cancer: which route to take? Expert Review of Gastroenterology and Hepatology 13(6): 515-517.
102. Jaworska J, Zalewska T, Sypecka J, Ziemka M (2019) Effect of the HDAC Inhibitor, sodium butyrate, on neurogenesis in a rat model of neonatal hypoxia-ischemia: Potential Mechanism of Action. Molecular Neurobiology.

103. Conte M, De Palma, Altucci L (2018) HDAC inhibitors as epigenetic regulators for cancer immunotherapy. The International Journal of Biochemistry \& Cell Biology 98: 65-74.

104. Sabit H, Mostafa F, Shimaa E, Osama A, Mokhtar M (2017) Vorinostat combined with DNMTi epigenetically controls the proliferation of lung cancer cells. International Journal of Science and Research (IJSR) 6(7): 855-860.

105. Salinas V, Marchat LA, Rincón D, Ruiz-García E, Astudillo V, et al. (2019) AngiomiRs: MicroRNAs driving angiogenesis in cancer. International Journal of Molecular Medicine 43(2): 657-670.

106. Sun X, Gribskov M (2018) MicroRNA and lncRNA databases and analysis, in reference module in life sciences. Elsevier.

107. de Brot S (2018) Chapter 20 - Epigenetic Control of MicroRNA expression and cancer, in cancer and noncoding RNAs. In: Chakrabarti DJ and Mitra DS (Eds.), Academic Press: Boston, Massachusetts, United States, pp. 373-380.

108. Camarillo C, Marchat LA, Ocampo E, Perez-Plasencia C, Hernandez O, et al. (2012) MetastamiRs: Non-coding microRNAs driving cancer invasion and metastasis. International Journal of Molecular Sciences 13(2): 1347-1379.

109. Monk D, Mackay DJG, Eggermann T, Maher ER, Riccio A (2019) Genomic imprinting disorders: lessons on how genome, epigenome and environment interact. Nature Reviews Genetics 20(4): 235-248.

110. Matsuura K (2018) Sex, genomic imprinting and social evolution?, in reference module in life sciences. Elsevier.

111. Monk D (2015) Genomic imprinting in the human placenta. American Journal of Obstetrics and Gynecology 213(4 Suppl): S152-S162.

112. Xiaoyan L, Xiong C, Zuo W, Junulin H (2009) Genetic imprinted gene PEG10 expression in deciduas of normal early pregnant women. Journal of Medical Colleges of PLA 24(6): 329-336.

113. Kingsley SL, Deyssenroth MA, Kelsey KT, Awad YA, Kloog I, et al. (2017) Maternal residential air pollution and placental imprinted gene expression. Environment International 108: 204-211.

114. Macdonald WA (2012) Epigenetic mechanisms of genomic imprinting: common themes in the regulation of imprinted regions in mammals, plants, and insects. Genetics Research International, pp. 585024-17.

115. Jelinic P, Shaw P (2007) Loss of imprinting and cancer. The Journal of Pathology 211(3): 261-268. 